\title{
Haloalkaliphilic spore-forming sulfidogens from soda lake sediments and description of Desulfitispora alkaliphila gen. nov., sp. nov.
}

\author{
Dimitry Y. Sorokin • Gerard Muyzer
}

Received: 12 January 2010/Accepted: 12 March 2010/Published online: 3 April 2010

(C) The Author(s) 2010. This article is published with open access at Springerlink.com

\begin{abstract}
An anaerobic enrichment with pyruvate as electron donor and thiosulfate at $\mathrm{pH} 10$ and $0.6 \mathrm{M} \mathrm{Na}^{+}$ inoculated with pasteurized soda lake sediments resulted in a sulfidogenic coculture of two morphotypes of obligately anaerobic haloalkaliphilic endospore-forming clostridia, which were further isolated in pure culture. Strain AHT16 was a thin long rod able to ferment sugars and pyruvate and to respire $\mathrm{H}_{2}$, formate and pyruvate using thiosulfate and fumarate as electron acceptors and growing optimally at $\mathrm{pH}$ 9.5. Thiosulfate was reduced incompletely to sulfide and sulfite. The strain was closely related (99\% sequence similarity) to a peptolytic alkaliphilic clostridium Natronincola peptidovorans. Strain AHT17 was a short rod with a restricted respiratory metabolism, growing with pyruvate and lactate as electron donor and sulfite, thiosulfate and
\end{abstract}

Communicated by A. Oren.

Nucleotide sequence accession numbers: the GenBank/EMBL accession number of the 16S-rRNA gene sequence of strains AHT 16 and AHT $17^{\mathrm{T}}$ are FJ788524 and FJ788525.

Electronic supplementary material The online version of this article (doi:10.1007/s00792-010-0310-y) contains supplementary material, which is available to authorized users.

\section{Y. Sorokin ( $\square)$}

Winogradsky Institute of Microbiology,

Russian Academy of Sciences,

Prospect 60-let Octyabrya 7/2, 117811 Moscow, Russia

e-mail: soroc@inmi.host.ru; d.sorokin@tudelft.nl

D. Y. Sorokin · G. Muyzer

Environmental Biotechnology Group,

Department of Biotechnology, Delft University of Technology,

Julianalaan 67, 2628 BC Delft, The Netherlands elemental sulfur as electron acceptors with a $\mathrm{pH}$ optimum 9.5. Thiosulfate was reduced completely via sulfite to sulfide. The ability of AHT17 to use sulfite explained the stability of the original coculture of the two clostridia-one member forming sulfite from thiosulfate and another consuming it. Strain AHT17 formed an independent deep phylogenetic lineage within the Clostridiales and is proposed as a new genus and species Desulfitisporum alkaliphilum gen. nov., sp. nov. (=DSM $22410^{\mathrm{T}}=\mathrm{UNIQEM}$ $\mathrm{U} 794^{\mathrm{T}}$ ).

Keywords Clostridia - Haloalkaliphilic - Soda lakes · Sulfidogenic $\cdot$ Sulfite $\cdot$ Thiosulfate

\section{Introduction}

Soda lakes are extreme habitats with a stable $\mathrm{pH}$ between 9 and 11 due to a presence of free sodium carbonate/bicarbonate, which can reach saturation (4 M alkalinity). Despite these harsh conditions, the element cycling in soda lakes, driven by a fully structured haloalkaliphilic prokaryotic community, is very active, especially at low to moderate salt concentrations (Zavarzin 2007). The sulfur cycle is one of the most active microbial cycles in soda lakes, even at hypersaline conditions, which is evident from the usually high acid-labile sulfide content in the sediments, the high-sulfate reduction rates, and the high viable numbers of sulfur-oxidizing bacteria (Gorlenko et al. 1999; Sorokin et al. 2004, 2006; Foti et al. 2007; Kulp et al. 2006).

In contrast to sulfur oxidation (Sorokin et al. 2006), sulfidogenesis at extremely haloalkaline conditions is not well understood. Until now, three haloalkaliphilic sulfatereducing bacteria (SRB), members of the order 
Desulfovibrionales (Deltaproteobacteria), have been cultivated from soda lake sediments, including the genera Desulfonatronovibrio (Zhilina et al. 1997), Desulfonatronum (Pikuta et al. 1998, 2003; Zhilina et al. 2005) and Desulfonatronospira (Sorokin et al. 2008a). Recently, it was extended to representatives of the order Desulfobacterales (Sorokin et al. 2010). Culture-independent studies of sulfate-reducing bacteria (SRB) in Mono Lake, California (Scholten et al. 2005), Wadi Natrun, Egypt (Mesbah et al. 2007) and Kulunda Steppe, Russia (Foti et al. 2007) also revealed mostly a presence of the deltaproteobacterial SRB lineages from Desulfovibrionales and Desulfobacterales. Although many of the sequences were grouped within the class Clostridia, their phylogenetic affiliation with the Gram-positive SRB could not be established with confidence.

So far, non-sulfate-reducing sulfidogens from alkaline habitats are represented by the sulfur-reducing Desulfurispirillum alkaliphilum, which was isolated from a bioreactor (Sorokin et al. 2007) and by two sulfur/thiosulfate reducers, Desulfurivibrio alkaliphilus and Dethiobacter alkaliphilus, isolated from soda lakes (Sorokin et al. 2008b). The latter, together with the alkali-tolerant clostridium Desulfitibacter alkalitolerans isolated from an anthropogenic habitat (Nielsen et al. 2006) are the only known culturable haloalkaliphilic Gram-positive sulfidogens.

In an attempt to investigate the presence of endosporeforming Desulfotomaculum-Desulfosporosinus-like SRB in soda lakes cultivation was performed after pasteurization of the inoculum, a mixture of sediment samples. In this paper, properties of two haloalkaliphilic non-sulfatereducing sulfidogenic clostridia completely reducing thiosulfate to sulfide in concert action are described.

\section{Methods}

Samples

Surface sediment samples $(2-10 \mathrm{~cm})$ were obtained from ten soda lakes in south-eastern Kulunda Steppe (Altai, Russia) in July 2008. The pH of the brines varied from 9.5 to 10.6 , the total salt concentration from 40 to $500 \mathrm{~g} \mathrm{l}^{-1}$, and the total soluble carbonate alkalinity from 0.3 to 4.0 M. The samples from individual lakes were pooled in equal proportions, vigorously homogenized by vortexing, and subjected to a short low-speed centrifugation to remove coarse particles. The resultant inoculum consisted of a fine colloidal fraction enriched with cells (according to fluorescent microscopy check). Before inoculation, the sample was heat-treated at $85^{\circ} \mathrm{C}$ for $30 \mathrm{~min}$ and added to the medium at $1 \%(\mathrm{v} / \mathrm{v})$.

\section{Cultivation}

The anaerobic enrichment and routine cultivation were performed at $30^{\circ} \mathrm{C}$ on a mineral medium containing sodium carbonate/bicarbonate buffer $\left(0.5 \mathrm{M}\right.$ total $\left.\mathrm{Na}^{+}, \mathrm{pH} 10\right)$, $0.1 \mathrm{M} \mathrm{NaCl}$, and $0.5 \mathrm{~g} \mathrm{l}^{-1}$ of $\mathrm{K}_{2} \mathrm{HPO}_{4}$. After sterilization, the medium was supplemented with $4 \mathrm{mM} \mathrm{NH}_{4} \mathrm{Cl}, 1 \mathrm{mM}$ $\mathrm{MgCl}_{2} \cdot 6 \mathrm{H}_{2} \mathrm{O}, 1 \mathrm{~mL} \mathrm{l}^{-1}$ each of acidic (Pfennig and Lippert 1966) and alkaline (Plugge 2005) trace metal solutions and $20 \mathrm{mg} \mathrm{l}^{-1}$ yeast extract. The medium was reduced by $1 \mathrm{mM}$ of $\mathrm{Na}_{2} \mathrm{~S} / 0.1 \mathrm{mM}$ dithionite, dispensed into the Hungate tubes or $100 \mathrm{~mL}$ serum bottles and made anoxic by five cycles of evacuation/flushing with argon gas. The electron donors were supplied at $10 \mathrm{mM}$ for sugars and $50 \mathrm{mM}$ for formate. Electron acceptors that were tested included $\mathrm{Na}_{2} \mathrm{SO}_{4}(20 \mathrm{mM}), \mathrm{Na}_{2} \mathrm{~S}_{2} \mathrm{O}_{3}(20 \mathrm{mM})$, $\mathrm{KNO}_{3}(10 \mathrm{mM}), \mathrm{KNO}_{2}, \mathrm{Na}_{2} \mathrm{SO}_{3}$, sodium selenate and selenite, sodium arsenate, DMSO (5 mM each), sodium fumarate $(20 \mathrm{mM}$; alone or with $2 \mathrm{mM}$ acetate as carbon source), and freshly prepared ferrihydrite $(50 \mathrm{mM})$ prepared according to Kostka and Nealson (1998). Elemental sulfur was sterilized as a $50 \%(\mathrm{w} / \mathrm{v})$ water suspension at $110^{\circ} \mathrm{C}$ for $60 \mathrm{~min}$ and used at final concentration $2 \mathrm{~g} \mathrm{l}^{-1}$. Growth at microoxic conditions was tested in the absence of the reductant with an oxygen concentration in the gas phase of $2 \%$. Solid alkaline media with a final salt concentration of $0.5 \mathrm{M} \mathrm{Na}^{+}$was prepared by $1: 1$ mixing of $4 \%$ (w/v) washed agar and $1 \mathrm{M} \mathrm{Na}^{+}$reduced anaerobic mineral medium at $50^{\circ} \mathrm{C}$ with doubled sulfide concentration. The plates were immediately placed in closed jars under the stream of argon with an oxygen-scavenging catalyzer (Oxoid) and incubated for up to 1 month before visible colonies appeared.

The $\mathrm{pH}$ dependence was examined at $\mathrm{Na}^{+}$content of $0.6 \mathrm{M}$, using the following filter-sterilized mineral media: for $\mathrm{pH}$ 6-8, 0.1 M HEPES and $\mathrm{NaCl}$; for $\mathrm{pH} 8.5-11.5$, a mixture of sodium bicarbonate/sodium carbonate containing $0.1 \mathrm{M} \mathrm{NaCl}$. Growth and sulfidogenesis resulted in a shift of initial $\mathrm{pH}$ values, especially at the $\mathrm{pH}$ extremes. Therefore, final $\mathrm{pH}$ values were taken to indicate the suitable range for growth and activity. The influence of salt concentration on growth and activity was investigated in sodium carbonate buffer containing $0.1-3.0 \mathrm{M}$ of total $\mathrm{Na}^{+}$ at $\mathrm{pH} 10$.

\section{Sulfidogenic activity of resting cells}

Cultures were grown in $1 \mathrm{~L}$ volume with pyruvate in the presence of an electron acceptor to induce the sulfidogenic capacity. The cells were harvested by centrifugation, washed with anoxic $0.5 \mathrm{M}$ sodium carbonate buffer, $\mathrm{pH} 10$, containing $1 \mathrm{mM} \mathrm{HS}^{-}$and resuspended in the same buffer at concentration $0.2 \mathrm{mg}$ protein $\mathrm{mL}^{-1} .2 \mathrm{~mL}$ 
portions of the suspension was dispensed in $7 \mathrm{ml}$ serum bottles, supplemented with sulfur electron acceptors and made anaerobic by evacuation/argon flushing. The reaction was started by injection of $20 \mathrm{mM}$ pyruvate. The bottles were incubated at $30^{\circ} \mathrm{C}$ with periodic sulfide analysis in $0.1 \mathrm{~mL}$ sample.

\section{Analytical procedures}

Sulfide/polysulfide-sulfane was precipitated in $10 \%(\mathrm{w} / \mathrm{v})$ $\mathrm{Zn}$ acetate and analyzed by the methylene blue method after separation from the supernatant (Trüper and Schlegel 1964). Thiosulfate and sulfite were analyzed by iodimetric titration after sulfide removal as $\mathrm{ZnS}$. Cell protein was measured by the Lowry method (Lowry et al. 1951) after removal of interfering $\mathrm{FeS}$ from the cell pellet by a double washing with $0.5 \mathrm{M} \mathrm{NaCl}$ acidified with $\mathrm{HCl}$ to $\mathrm{pH} 4$. Organic compounds (glucose and carbonic acids) in neutralized supernatants were detected by HPLC [column HPX-87-H (BioRad) at $60^{\circ} \mathrm{C}$; detector UV/IR; carrier $5 \mathrm{mM} \mathrm{H}_{2} \mathrm{SO}_{4}$ at $\left.0.6 \mathrm{~mL} / \mathrm{min}\right]$.

Phase-contrast microphotographs were made with a Zeiss Axioplan Imaging 2 microscope (Göttingen, Germany). For electron microscopy of total preparations, the cells from $2 \mathrm{~mL}$ of the exponentially growing liquid cultures were collected, resuspended in $0.5 \mathrm{M} \mathrm{NaCl}$, fixed with glutaraldehyde (final concentration of $3 \% \mathrm{v} / \mathrm{v}$ ) and contrasted with $1 \%(\mathrm{w} / \mathrm{v})$ neutralized phosphotungstic acid. Cellular fatty acids were extracted with a mixture of methanol-chloroform and analyzed by GC-MS according to Zhilina et al. (1997).

\section{Genetic and phylogenetic analysis}

Isolation of genomic DNA and determination of the $\mathrm{G}+\mathrm{C}$ content of the DNA from pure cultures was performed according to Marmur (1961) and Marmur and Doty (1962). For the 16S-rRNA gene sequencing, the DNA was extracted from the cells using alkaline SDS lysis at $60^{\circ} \mathrm{C}$ (Birnboim and Doly 1979) and purified with the Wizard Preps kit (Promega, USA). The nearly complete 16S rRNA gene was obtained from the pure cultures using general bacterial PCR primers GM3f (5'-AGAGTTTGATCCTG GCTCAG-3') and GM4r (5'TACGGTTACCTTGTTACGACTT-3') (Schäfer and Muyzer 2001). The PCR products were purified using the Qiagen Gel Extraction Kit (Qiagen, The Netherlands). The sequences were first compared with sequences stored in GenBank using the BLAST algorithm. Subsequently, the sequences were imported into the ARB software program (Ludwig et al. 2004), automatically aligned, and added to a phylogenetic tree using the Quick-add tool. The SILVA SSU_reference database version 1.4 was used to select for sequences of other taxa. The alignment created by ARB was curated manually. Sub-trees were then built using the neighbourjoining algorithm with automatic selected correction settings.

\section{Results and discussion}

Enrichment and isolation of pure cultures of sporeforming sulfidogens from soda lakes

Initial enrichment cultures with pasteurized sediments as inoculum were set with sulfate as electron acceptor and lactate, ethanol, methanol and CO (20\% v/v) as electron

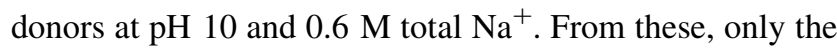
combination ethanol/sulfate produced sulfide during the first two 1:100 transfers and then stopped. From the primary ethanol/sulfate enrichment additional transfers were made with ethanol/sulfite, pyruvate/sulfate and pyruvate/ thiosulfate. Only the latter combination yielded a stable sulfidogenic mixed culture consisting of two different morphotypes of endospore-forming bacteria. A numerically more dominant morphotype represented by long thin rods was separated from less abundant short thick rods by repetitive dilution to extinction in liquid medium with pyruvate/thiosulfate. It was designated strain AHT16 (Fig. 1a). The second morphotype, forming mixed colonies with AHT16, produced much more spores on solid medium than strain AHT16, which favored the isolation in pure culture after heat treatment of the colony material. The treated material was further used in dilution series on liquid medium with pyruvate/thiosulfate, eventually resolving the second member of the consortium in pure culture, strain AHT17 (Fig. 1b, c).

\section{Identification of the isolates}

Phylogenetic analysis, based on 16S rRNA gene sequencing, placed both isolates in the order Clostridiales, but with different affiliations (Fig. 2). Strain AHT16 is a member of the clostridial cluster XI (Wiegel et al. 2006) closely related (99.4\% sequence similarity) to Natronincola peptidovorans Z-7031, which was isolated from a soda lake and described as an obligate fermentative peptolytic alkaliphile (Zhilina et al. 2009). However, it must be pointed out that apparently, both strains Z-7031 and AHT16 are more closely related to the genus Anaerovirgula, a moderate haloalkaliphilic versatile fermentative bacterium from hypersaline alkaline Owens Lake (Pikuta et al. 2006), than to the genus Natronincola. The sequence of Anaerovirgula has not been included into the phylogenetic analysis by Zhilina et al. (2009) which probably resulted in the wrong identification. The strain has been deposited in DSMZ 

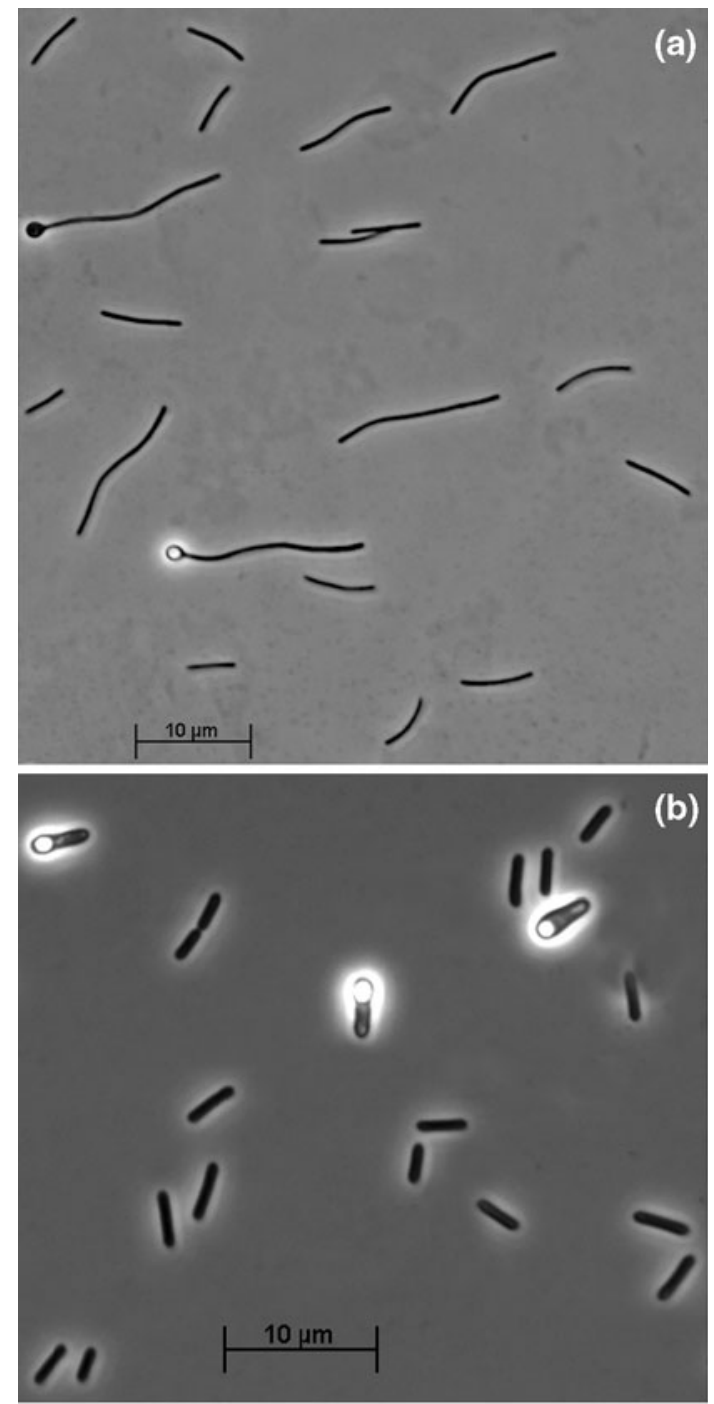

(c)

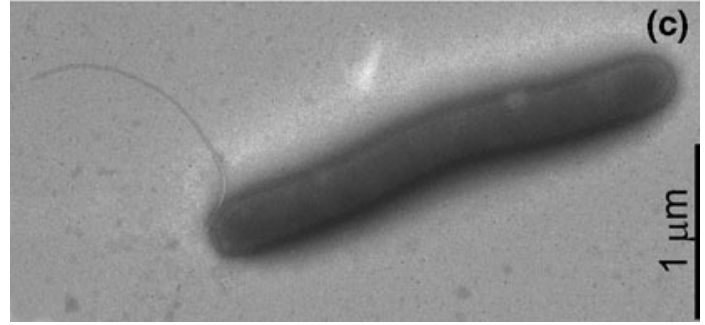

Fig. 1 Cell morphology of strains AHT16 (a), and AHT17 (b, c). a, b Phase-contrast microphotographs, c total electron microphotographs of positively stained cell

(Germany) under the number DSM22429 and in UNIQEM (Moscow) as U 793.

Strain AHT17 represented an independent deep lineage within the family Peptococcaceae with spore-forming alkali-tolerant sulfidogen Desulfitibacter alkalitolerans as a closest cultured relative ( $87.4 \%$ sequence similarity). Both neighbor-joining with Olsen correction, and maximum likelihood algorithms clustered AHT17 with
Desulfitobacter alkalitolerans with high bootstrap values (92\%). Other members of this family distinguished by their dissimilatory sulfidogenic metabolism include the genera Desulfotomaculum, Desulfosporosinus, Desulfitobacterium and Desulfurispora.

\section{Cellular fatty acid analysis}

Three dominant fatty acids $(16: 1 \omega 7 \mathrm{c}, 16: 0$ and 14:0) were identified in the membrane lipids of strain AHT16 comprising more than $70 \%$ of the total. In AHT17 there were two obviously dominating fatty acids, 16:1 105 and $16: 1 \omega 7 \mathrm{c}$, which made up of $50 \%$ from the total (see Supplementary Table).

\section{Metabolic properties}

The two isolates were very different in their metabolic profiles (summarized in Table 1). Strain AHT16 is a fermentative bacterium, utilizing a number of hexoses (glucose, fructose, galacturonic acid, galactose, glucuronic acid, ramnose, and lactose) and xylose. It also can ferment pyruvate. Apart from fermentation, the bacterium was capable of anaerobic respiration with thiosulfate and fumarate as electron acceptors using $\mathrm{H}_{2}$ and formate (with acetate as $\mathrm{C}$ source) for lithotrophic growth and pyruvate for heterotrophic growth. Chemolithoautotrophy was not observed. The maximum amount of sulfide formed during thiosulfate reduction was $15 \mathrm{mM} \mathrm{HS}^{-} / 13$ days. Thiosulfate was reduced incompletely to sulfide and sulfite, which was not surprising because the latter could not serve as the electron acceptor for this bacterium. The addition of thiosulfate markedly influenced the growth pattern on fermentable substrates, such as pyruvate and glucose, in strain AHT16. In the presence of thiosulfate, the growth yield on pyruvate was doubled and with glucose even tripled. A switch to anaerobic respiration was accompanied by a dramatic increase in the formation of the end product formate (Table 2).

Strain AHT17 is a strictly respiratory anaerobe (except for the ability to ferment pyruvate, which is common for sulfate-reducing bacteria) with a very restricted metabolism (see Table 1). It used pyruvate and lactate as electron donors with thiosulfate, sulfite and elemental sulfur as electron acceptors. Utilization of sugars, fermentation and lithotrophic growth with $\mathrm{H}_{2}$ or formate was not observed. In contrast to AHT16, thiosulfate respiration was slow with a maximum $\mathrm{HS}^{-}$formation of $5 \mathrm{mM} / 13$ days, but it was a complete reduction of both sulfane and sulfone atoms of thiosulfate to sulfide. The latter is explained by the ability of this bacterium to use sulfite as the electron donor, albeit at relatively low concentrations (concentrations above 
Fig. 2 Phylogenetic position based on $16 \mathrm{~S}$ rRNA gene sequence analysis of strains AHT16 and AHT17 within the class Clostridia. The tree was constructed using neighbourjoining. The scale bar represents five nucleotide changes per 100 nucleotides
Syntrophobotulus glycolicus (X99706) Dehalobacter restrictus (Y10164)

Desulfosporosinus orientis (Y11570)

Desulfitobacterium hafniense (AJ276701)

Thermincola ferriacetica (AY631277)

Dehalobacterium formicoaceticum (X86690)

Desulfotomaculum kuznetso (AY036904)

Desulfotomaculum geothermicum (Y11567)

Desulfotomaculum nigrificans (AB026550)

Desulfotomaculum alkaliphilum (AF097024)

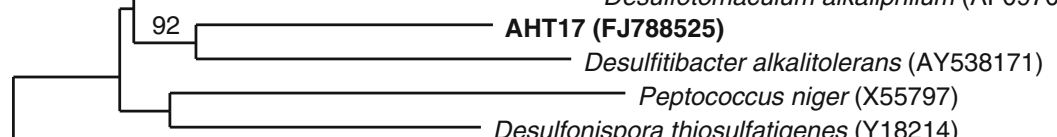

Desulfonispora thiosulfatigenes (

100 AHT16 (FJ788524)

- Natronincola peptidovorans (EF382661)

- Natronincola ferrireducens (EU878275)

Anaerovirgula multivorans (AB201750)

Natronincola histidinovorans (Y16716)

- Alkaliphilus crotonatoxidans (AF467248)

Alkaliphilus metalliredigenes (AY137848)

Tindallia magadiensis (Y15626)

Anoxynatronum sibiricum (AF522323)

- Clostridium sticklandii (M26494)

Clostridium litorale (X77845)

Clostridium difficile (X73450)

$5 \%$

Table 1 Comparative properties of the novel haloalkaliphilic sulfidogens and their closest relatives

\begin{tabular}{|c|c|c|c|c|c|}
\hline Property & AHT 16 & $\begin{array}{l}\text { Natronincola } \\
\text { peptidovorans }\end{array}$ & AHT17 & $\begin{array}{l}\text { Desulfitibacter } \\
\text { alkalitolerans }\end{array}$ & $\begin{array}{l}\text { Desulfitibacterium } \\
\text { hafniense }\end{array}$ \\
\hline Morphology & $\begin{array}{l}\text { Long motile rod with } \\
\text { round terminal } \\
\text { endospore }\end{array}$ & $\begin{array}{l}\text { Long motile rod with } \\
\text { round terminal } \\
\text { endospore }\end{array}$ & $\begin{array}{l}\text { Short motile rod with } \\
\text { round terminal } \\
\text { endospore }\end{array}$ & $\begin{array}{l}\text { Long motile rod with } \\
\text { round terminal } \\
\text { endospore }\end{array}$ & $\begin{array}{l}\text { Long motile rod with } \\
\text { round terminal } \\
\text { endospore }\end{array}$ \\
\hline \multicolumn{6}{|l|}{ Fermentation of: } \\
\hline Sugars & + & - & - & - & - \\
\hline Amino acids & - & + & - & + & - \\
\hline Pyruvate & + & + & + & n.d. & + \\
\hline Electron donors & $\mathrm{H}_{2}$, formate, pyruvate & None & Pyruvate, lactate & $\begin{array}{l}\text { Formate, lactate, } \\
\text { pyruvate, methanol, } \\
\text { betain, choline }\end{array}$ & Pyruvate, tryptophan \\
\hline $\begin{array}{l}\text { Electron acceptors } \\
\text { for anaerobic } \\
\text { respiration }\end{array}$ & Thiosulfate, fumarate & None & $\begin{array}{l}\text { Thiosulfate, sulfite, } \\
\text { sulfur }\end{array}$ & $\begin{array}{l}\text { Thiosulfate, sulfite, } \\
\text { sulfur, nitrate, nitrite }\end{array}$ & $\begin{array}{l}\text { Thiosulfate, sulfite, } \\
\text { nitrate }\end{array}$ \\
\hline $\begin{array}{l}\text { Dominant cellular } \\
\text { fatty acids }\end{array}$ & $16: 1 \omega 7 \mathrm{c}, 16: 0,14: 0$ & $\begin{array}{r}16: 1 \omega 7 \mathrm{c}, 16: 0, \\
18: 1 \omega 9,15: 0\end{array}$ & $16: 1 \omega 5,16: 1 \omega 7 \mathrm{c}$ & n.d. & n.d. \\
\hline Alkaliphily & + & + & + & + & - \\
\hline Salt dependence & + & + & + & - & - \\
\hline $\begin{array}{l}\mathrm{G}+\mathrm{C} \text { content } \\
(\mathrm{mol} \%)\end{array}$ & 34.3 & 35.5 & 37.9 & 41.6 & 47 \\
\hline Habitat & & oda lakes & & $\begin{array}{r}\text { Municipal water } \\
\text { heating system }\end{array}$ & Municipal sludge \\
\hline
\end{tabular}

Natronincola peptidovorans (Zhilina et al. 2009); Desulfitibacter alkalitolerans (Nielsen et al. 2006); Desulfitobacterium hafniense (Christiansen and Ahring 1996)

n.d. no data

$5 \mathrm{mM}$ inhibited growth). Maximum sulfidogenic activity with lactate as electron donor was observed with elemental sulfur as acceptor $(67 \mathrm{mM}$ sulfane of
$\mathrm{HS}^{-}+$polysulfide/13 days). Therefore, in its essential properties, strain AHT17 represented a typical Grampositive sulfidogen, similar to Desulfitobacterium and 
Table 2 Influence of thiosulfate $(20 \mathrm{mM})$ on anaerobic growth of strain AHT16 with pyruvate and glucose $(10 \mathrm{mM})$

\begin{tabular}{|c|c|c|c|c|}
\hline \multirow[t]{2}{*}{ Growth balance } & \multicolumn{2}{|c|}{ Pyruvate $(20 \mathrm{mM})$} & \multicolumn{2}{|c|}{ Glucose $(10 \mathrm{mM})$} \\
\hline & $-\mathrm{S}_{2} \mathrm{O}_{3}{ }^{2-}$ & $+\mathrm{S}_{2} \mathrm{O}_{3}{ }^{2-}$ & $-\mathrm{S}_{2} \mathrm{O}_{3}{ }^{2-}$ & $+\mathrm{S}_{2} \mathrm{O}_{3}{ }^{2-}$ \\
\hline Biomass $\left(\mathrm{OD}_{600}\right)$ & 0.08 & 0.150 & 0.060 & 0.180 \\
\hline $\begin{array}{l}\text { Consumed } \\
\text { substrate }(\mathrm{mM})\end{array}$ & 15 & 20 & 2.5 & 6.0 \\
\hline Acetate $(\mathrm{mM})$ & 7 & 1 & 5 & 1 \\
\hline Formate (mM) & 5 & 28 & 2.5 & 32 \\
\hline $\mathrm{HS}^{-}(\mathrm{mM})$ & - & 15.0 & - & 20.0 \\
\hline
\end{tabular}

Table 3 Sulfidogenic activity [nmol $(\mathrm{mg} \text { protein } \mathrm{h})^{-1}$ ] of washed cells grown with pyruvate and thiosulfate (AHT16) or sulfite (AHT17)

\begin{tabular}{lcc}
\hline Acceptor & AHT16 & AHT17 \\
\hline $\mathrm{S}_{2} \mathrm{O}_{3}{ }^{2-}$ & 380 & 90 \\
$\mathrm{SO}_{3}{ }^{2-}$ & 0 & 390 \\
$\mathrm{~S}_{8}$ & 110 & 840 \\
\hline
\end{tabular}

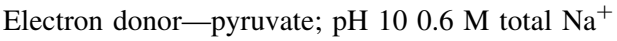

Desulfitibacter, which are different from the classical SRB in their inability to activate sulfate.

Short-term experiments with washed cells grown on pyruvate + thiosulfate (AHT16) or pyruvate + sulfite (AHT17) showed that, despite the absence of growth with sulfur, strain AHT16 was still able to reduce it, although much less actively, than the cells of strain AHT17. It also confirmed the lack of sulfite reductase in AHT16 and showed that the latter is a very active enzyme in AHT17 (Table 3).

The essential physiology of two organisms provided a perfect reason of their selection and stable coexistence in mixed anaerobic enrichment cultures on pyruvate + thiosulfate. Strain AHT16 is a very active thiosulfate reducer, but it produces sulfite, i.e., most of the accepting power is unused. This leaves a place for the second organism, strain AHT17, which was less active with thiosulfate, but used the byproduct of thiosulfate reduction by strain AHT16 making utilization of the electron-accepting potential of thiosulfate complete. A combination of the two pure cultures demonstrated that the consortium was more efficient in utilization of pyruvate with thiosulfate as electron acceptor than the individual strains: the final growth yield of the mixed culture was $75 \%$ higher than for the pure culture of strain AHT16 and $60 \%$ higher than for the pure culture of strain AHT17.

Influence of $\mathrm{pH}$ and salt on growth and sulfidogenic activity

Growth and sufidogenic activity of washed cells were optimal for both strains within the alkaline $\mathrm{pH}$ range with a maximum $\mathrm{pH}$ 9.5. Both strains were obligately, but moderately alkaliphilic with a lower $\mathrm{pH}$ limit above $\mathrm{pH} 8$ and a higher $\mathrm{pH}$ limit at 10.3. Sulfidogenic activity of washed cells, however, was still present up to pH 11 (Fig. 3). The salt tolerance, tested in a sodium carbonate/bicarbonate buffer at $\mathrm{pH} 10$, was relatively low in comparison with the salinity of their habitat, with a maximum growth rate and sulfidogenic activity at $0.4 \mathrm{M}$ total $\mathrm{Na}^{+}$(Fig. 4). Probably such organisms find micronishes with much lower salinity than the bulk or proliferate only during short spring periods of lake dilution.

In conclusion, we were unable to find a spore-forming SRB, such as Desulfotomaculum or Desulfosporosinus, in soda lakes, even after elimination of the deltaproteobacterial sulfidogens by pasteurization of the inoculum. Instead, other types of clostridial sulfidogens were selected reducing thiosulfate to sulfide in a concerted action. Strain AHT16 reduced thiosulfate to sulfite, while strain AHT17 subsequently reduced sulfite to sulfide. Strain AHT17 resembled the sulfite-reducing clostridia Desulfitibacter an Desilfitobacterium but clearly differed from them by distant phylogeny and obligate alkaliphily, and, therefore is proposed here as a novel genus and species Desulfitispora alkaliphila gen. nov., sp. nov.

\section{Description of Desulfitispora gen. nov.}

[Desulfitispora (De.sul.fi.ti.spo'ra) L. pref. de from, off, away; N. L. n. sulfis-itis sulfite; N.L. fem. n. spora (from Gr. n. spora), a seed and in biology a spore; N. L. fem. n. Desulfitispora spore-forming bacterium-reducing sulfite].

Gram-positive, endospore-forming rods. Obligately anaerobic with respiratory metabolism. Use sulfur compounds, but not sulfate, as electron acceptor, and short-chain organic acids as electron donors. Obligately alkaliphilic and moderately salt tolerant. A member of the family Peptococcaceae within the order Clostridiales. The type species is $D$. alkaliphila. Habitat—soda lakes.

\section{Description of Desulfitispora alkaliphila sp. nov.}

al.ka.li.phi'la. N. L. n. alkali (from Arabic article $a$, the and Arabic n. qaliy, ashes of saltwort), alkali; N.L. adj. philus from Gr. adj. philos loving; N. L. fem. adj. alkaliphila, loving alkaline conditions.

Cells are Gram-positive rods forming terminal endospores with swollen sporangia, $0.7-0.8 \times 2-4 \mu \mathrm{m}$, motile with a subterminal flagellum. Strictly anaerobic with respiratory metabolism. Uses thiosulfate, sulfite and elemental sulfur as electron acceptors. Utilizes lactate and pyruvate as both electron donor and carbon source. 
Fig. 3 Influence of $\mathrm{pH}$ (at $0.6 \mathrm{M} \mathrm{Na}^{+}$) on growth (closed circles) and sulfidogenic activity of washed cells (open circles) in strains AHT16 (a) and AHT17 (b). Strain AHT16 was grown and the cells were tested with pyruvate and thiosulfate. Strain AHT17 was grown and the cells were tested with pyruvate and sulfite $\mathrm{pH}$ 10) in carbonate/bicarbonate buffer on growth (closed circles) and sulfidogenic activity of washed cells (open circles) in strains AHT16 (a) and AHT17 (b). Strain AHT16 was grown and the cells were tested with pyruvate and thiosulfate. Strain AHT17 was grown and the cells were tested with pyruvate and sulfite

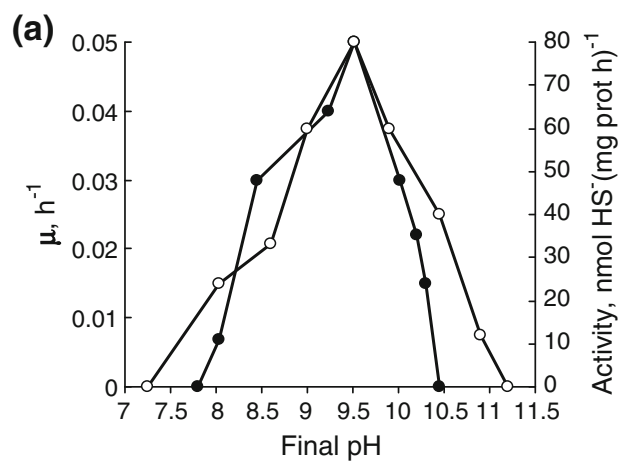

(a)

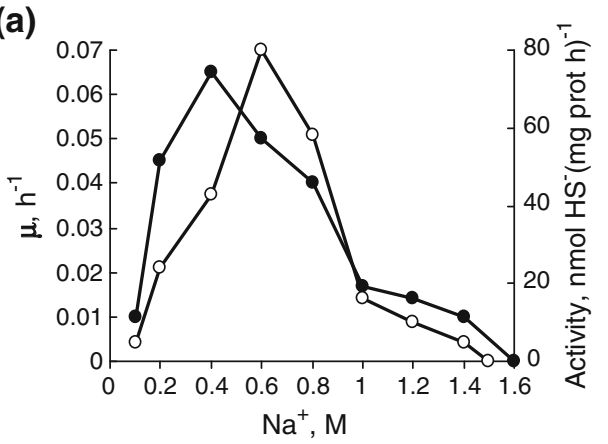

(b)

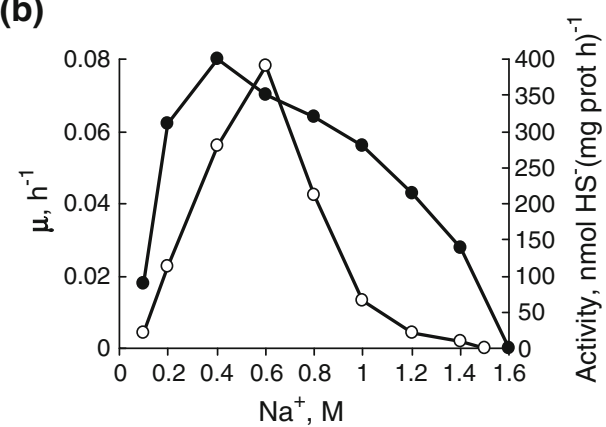

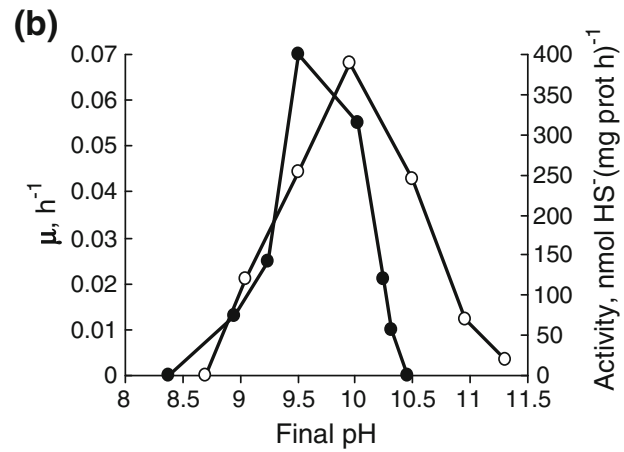

Pyruvate can be fermented. Obligately alkaliphilic with a $\mathrm{pH}$ range for growth between 8.5 and 10.3 and an optimum at pH 9.5 and moderately salt tolerant with a total $\mathrm{Na}^{+}$ range for growth from 0.1 to $1.4 \mathrm{M}$ (optimum at $0.4 \mathrm{M}$ ). Mesophilic, with a maximum temperature for growth at $43^{\circ} \mathrm{C}$. The dominant cellular fatty acids include $16: 1 \omega 5$ and $16: 1 \omega 7 \mathrm{c}$. The $\mathrm{G}+\mathrm{C}$ content of the genomic DNA is $37.9 \pm 0.5 \mathrm{~mol} \%\left(T_{\mathrm{m}}\right)$. The type strain is AHT17 ${ }^{\mathrm{T}}$ (=DSM $22410=$ UNIQEM U794). Isolated from mixed sample of sediments from different hypersaline soda lakes in Kulunda Steppe (Altai, Russia). The GenBank 16S rRNA gene sequence accession number is FJ788525.

Acknowledgments This work was supported by the RFBR Grant 010-04-00152.

Open Access This article is distributed under the terms of the Creative Commons Attribution Noncommercial License which permits any noncommercial use, distribution, and reproduction in any medium, provided the original author(s) and source are credited.

\section{References}

Birnboim HC, Doly J (1979) A rapid alkaline extraction procedure for screening recombinant plasmid DNA. Nucl Acids Res 7:15131523

Christiansen N, Ahring BK (1996) Desulfitobacterium hafniense sp. nov., an anaerobic, reductively dechlorinating bacterium. Int $\mathbf{J}$ Syst Bacteriol 46:442-448

Foti M, Sorokin DY, Lomans B, Mussman M, Zakharova EE, Pimenov NV, Kuenen JG, Muyzer G (2007) Diversity, activity and abundance of sulfate-reducing bacteria in saline and hypersaline soda lakes. Appl Environ Microbiol 73:2093-2100

Gorlenko VM, Namsaraev BB, Kulyrova AV, Zavarzina DG, Zhilina TN (1999) Activity of sulfate-reducing bacteria in the sediments of the soda lakes in south-east Transbaikal area. Microbiology (Moscow, English Translation) 68:580-586

Kostka J, Nealson KH (1998) Isolation, cultivation and characterization of iron- and manganese-reducing bacteria. In: Burlage RS et al (eds) Techniques in microbial ecology. Oxford University Press, USA, p 63

Kulp TR, Hoeft SE, Miller LG, Saltikov C, Murphy JN, Han S, Lanoil B, Oremland RS (2006) Dissimilatory arsenate and sulfate reduction in sediments of two hypersaline, arsenic-rich soda lakes: Mono and Searles Lakes, California. Appl Environ Microbiol 72:6514-6526

Lowry OH, Rosebrough NJ, Farr AL, Randall RJ (1951) Protein measurement with Folin phenol reagent. J Biol Chem 193:265275

Marmur J (1961) A procedure for isolation of DNA from microorganisms. J Mol Biol 3:208-214

Marmur J, Doty P (1962) Determination of the base composition of deoxyribonucleic acid from microorganisms. J Mol Biol 5:109_ 118

Mesbah NM, Abou-El-Ela SH, Wiegel J (2007) Novel and unexpected prokaryotic diversity in water and sediments of the alkaline, hypersaline lakes of the Wadi an Natrun, Egypt. Microbial Ecol 54:598-616

Nielsen MB, Kjeldsen KU, Ingvorsen K (2006) Desulfitibacter alkalitolerans gen. nov., sp. nov., an anaerobic, alkalitolerant, sulfite-reducing bacterium isolated from a district heating plant. Int J Syst Evol Microbiol 56:2831-2836

Pfennig N, Lippert KD (1966) Über das Vitamin $B_{12}$-Bedürfnis phototropher Schwefelbakterien. Arch Microbiol 55:245-256

Pikuta EV, Zhilina TN, Zavarzin GA, Kostrikina NA, Osipov GA, Rainey FA (1998) Desulfonatronum lacustre gen. nov., sp. nov.: a new alkaliphilic sulfate-reducing bacterium utilizing ethanol. Microbiology (Moscow, English translation) 67:105-113 
Pikuta EV, Hoover RB, Bej AK, Marsic D, Whitman WB, Cleland D, Krader P (2003) Desulfonatronum thiodismutans sp. nov., a novel alkaliphilic, sulfate-reducing bacterium capable of lithoautotrophic growth. Int J Syst Evol Microbiol 53:1327-1332

Pikuta EV, Itoh T, Krader P, Tang J, Whitman W, Hoover RB (2006) Anaerovirgula multivorans gen. nov., sp. nov., a novel sporeforming, alkaliphilic anaerobe isolated from Owens Lake, California, USA. Int J Syst Evol Microbiol 56:2623-2629

Plugge CM (2005) Anoxic media design, preparation, and considerations. Methods Enzymol 397:3-16

Schäfer H, Muyzer G (2001) Denaturing gradient gel electrophoresis in marine microbial ecology. In: Paul JH (ed) Methods in microbiology. Academic, New York

Scholten JCM, Joye SB, Hollibaugh JT, Murrell JC (2005) Molecular analysis of the sulfate reducing and archaeal community in a meromictic soda lake (Mono Lake, California) by targeting 16S rRNA, mcrA, apsA, and $d s r \mathrm{AB}$ genes. Microb Ecol 50:29-39

Sorokin DY, Gorlenko VM, Namsaraev BB, Namsaraev ZB, Lysenko AM, Eshinimaev BT, Khmelenina VN, Trotsenko YA, Kuenen JG (2004) Prokaryotic communities of the north-eastern Mongolian soda lakes. Hydrobiologia 522:235-248

Sorokin DY, Banciu H, Robertson LA, Kuenen JG (2006) Haloalkaliphilic sulfur-oxidizing bacteria. In: Dworkin $\mathrm{M}$ et al (eds) The Prokaryotes, V 2. Springer, New York, pp 969-984

Sorokin DY, Foti M, Tindall BJ, Muyzer G (2007) Desulfurispirillum alkaliphilum gen. nov. sp. nov., a novel obligately anaerobic sulfur- and dissimilatory nitrate-reducing bacterium from a fullscale sulfide-removing bioreactor. Extremophiles 11:363-370

Sorokin DY, Tourova TP, Henstra AM, Stams AJM, Galinski EA, Muyzer G (2008a) Sulfidogenesis at extremely haloalkaline conditions by Desulfonatronospira thiodismutans gen. nov., sp. nov., and Desulfonatronospira delicata sp. nov.-a novel lineage of Deltaproteobacteria from hypersaline soda lakes. Microbiology (UK) 154:1444-1453
Sorokin DY, Tourova TP, Mussmann M, Muyzer G (2008b) Dethiobacter alkaliphilus gen. nov. sp. nov., and Desulfurivibrio alkaliphilus gen. nov. sp. nov.- two novel representatives of reductive sulfur cycle from soda lakes. Extremophiles 12:431439

Sorokin DY, Detkova EN, Muyzer G (2010) Propionate and butyrate dependent bacterial sulfate reduction at extremely haloalkaline conditions and description of Desulfobotulus alkaliphilus sp. nov. Extremophiles 14:71-77

Trüper HG, Schlegel HG (1964) Sulfur metabolism in Thiorhodaceae. 1. Quantitative measurements on growing cells of Chromatium okenii. Antonie van Leeuwenhoek 30:225-238

Wiegel J, Tanner R, Rainey FA (2006) An introduction to the family Clostridiaceae. In: Dworkin M et al (eds) Prokaryotes, V 4. Springer, NY, pp 654-678

Zavarzin GA (Ed.) (2007). Alkaliphilic microbial communities. In: Transactions of the Winogradsky Institute of Microbiology, V XIV, Nauka, Moscow, 396 pp (in Russian)

Zhilina TN, Zavarzin GA, Rainey FA, Pikuta EN, Osipov GA, Kostrikina NA (1997) Desulfonatronovibrio hydrogenovorans gen. nov., sp. nov., an alkaliphilic, sulfate-reducing bacterium. Int J Syst Bacteriol 47:144-149

Zhilina TN, Zavarzina DG, Kuever J, Lysenko AM, Zavarzin GA (2005) Desulfonatronum cooperativum sp.nov., a novel hydrogenotrophic, alkaliphilic, sulfate-reducing bacterium, from a syntrophic culture growing on acetate. Int J Syst Evol Microbiol 55:1001-1006

Zhilina TN, Zavarzina DG, Osipov GA, Kostrikina NA, Tourova TP (2009) Natronincola ferrireducens sp. nov., and Natronincola peptidovorans sp. nov., new anaerobic alkaliphilic peptolytic iron-reducing bacteria isolated from soda lakes. Microbiology (Moscow, English Translation) 78:455-467 